\title{
Mastoid osteoma with stenosis of transverse and sigmoid sinuses as a cause of pseudotumor cerebri
}

Gustavo Lima Guarneri, MD, and Bernardo Corrêa de Almeida Teixeira, MD

Neurology ${ }^{\circledR}$ 2019;93:37-38. doi:10.1212/WNL.0000000000007727

Figure 1 Neuroimaging
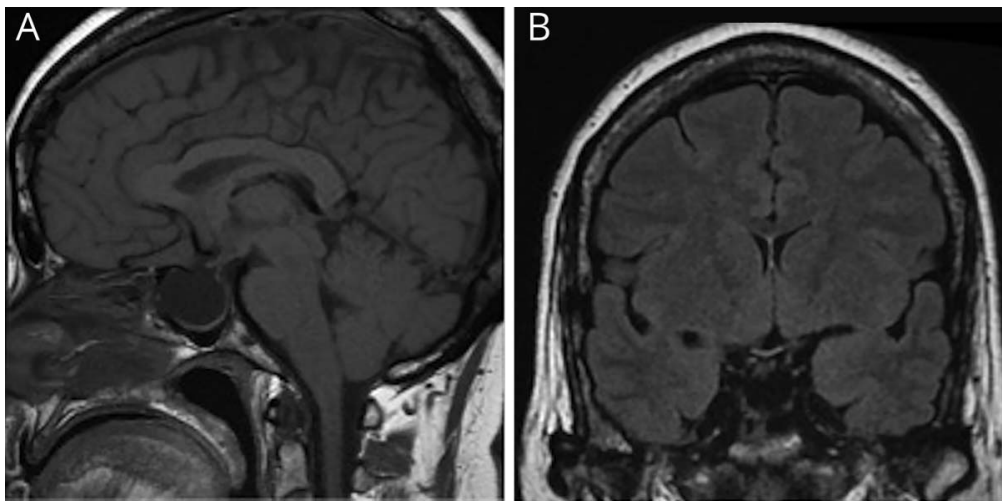

(A) Partial empty sella with bone remodeling. (B) Atrophic and degenerated bilateral optic nerve and chiasm.
Correspondence

Dr. Guarneri

gustavoguarneri@

hotmail.com

Figure 2 Expansive mastoid lesion
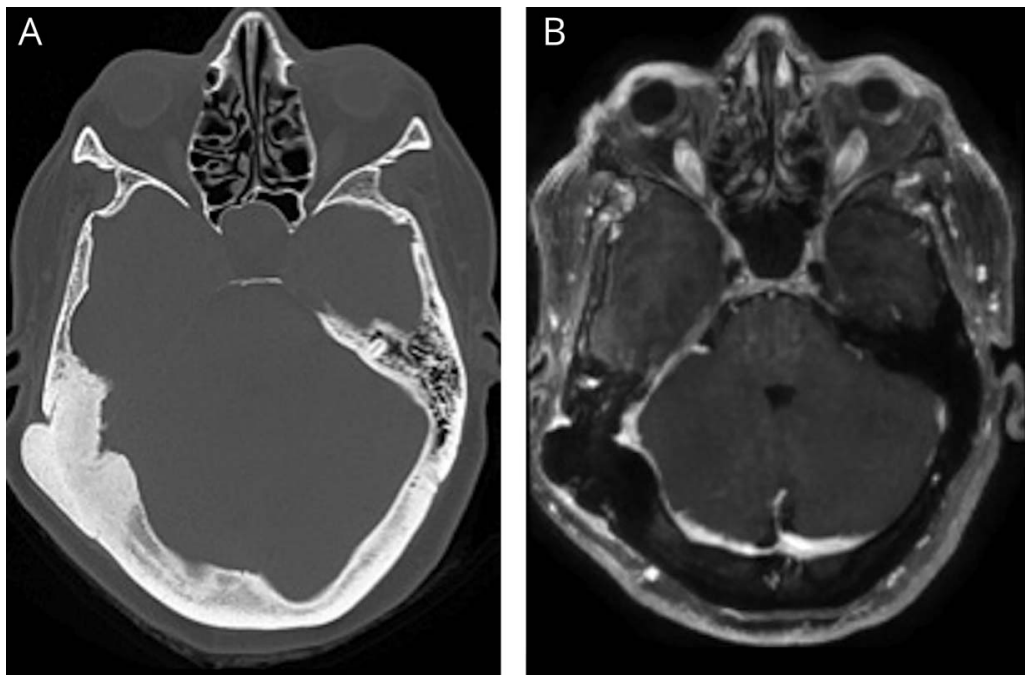

(A) Large right temporal bone osteoma involving the sigmoid sulcus. Enlarged sella turcica is also visible. (B) Displacement and stenosis of right transverse sinus. Also note hypoplastic left transverse sinus.

From Hospital de Clínicas (G.L.G.) and Neuroradiology Section (B.C.d.A.T.), Federal University of Paraná, Curitiba, Brazil.

Go to Neurology.org/N for full disclosures. Funding information and disclosures deemed relevant by the authors, if any, are provided at the end of the article. 
A 54-year-old woman with progressive visual loss and signs of hyperprolactinemia underwent neuroimaging that shows partial empty sella (figure 1A), atrophic bilateral optic nerve (figure 1B), and expansive mastoid lesion (figure 2), causing stenosis of the right transverse and sigmoid sinuses (figure $2 \mathrm{~B}$ ). CSF analysis was normal, except for high opening pressure $\left(41 \mathrm{~cm} \mathrm{H}_{2} \mathrm{O}\right)$. The clinical and radiologic findings are diagnostic of pseudotumor cerebri, also known as idiopathic intracranial hypertension. This disorder is usually related to stenosis of unknown cause of the larger lateral sinuses, which are commonly asymmetric. ${ }^{1}$ Rarely an anatomic lesion can be determined by neuroimaging. ${ }^{2}$

\section{Study funding}

No targeted funding reported.

\section{Disclosure}

The authors report no disclosures relevant to the manuscript. Go to Neurology.org/N for full disclosures.
Appendix Authors

\begin{tabular}{llll}
\hline Name & Location & Role & Contribution \\
\hline $\begin{array}{l}\text { Gustavo Lima } \\
\text { Guarneri }\end{array}$ & $\begin{array}{l}\text { Hospital de } \\
\text { Clínicas, } \\
\text { Paraná }\end{array}$ & Author & $\begin{array}{l}\text { Research, wrote the } \\
\text { manuscript }\end{array}$ \\
$\begin{array}{l}\text { Bernardo Corrêa } \\
\text { de Almeida } \\
\text { Teixeira }\end{array}$ & $\begin{array}{l}\text { Hospital de } \\
\text { Clínicas, } \\
\text { Paraná }\end{array}$ & Author & $\begin{array}{l}\text { Research, revised the } \\
\text { manuscript for } \\
\text { intellectual content }\end{array}$ \\
\hline
\end{tabular}

\section{References}

1. Degnan AJ, Levy LM. Pseudotumor cerebri: brief review of clinical syndrome and imaging findings. AJNR Am J Neuroradiol 2011;32:1986-1993.

2. Hingwala DR, Kesavadas C, Thomas B, Kapilamoorthy TR, Sarma PS. Imaging signs in idiopathic intracranial hypertension: are these signs seen in secondary intracranial hypertension too? Ann Indian Acad Neurol 2013;16:229-233.

\section{Subspecialty Alerts by E-mail!}

Customize your online journal experience by signing up for e-mail alerts related to your subspecialty or area of interest. Access this free service by clicking on the "My Alerts" link on the home page. An extensive list of subspecialties, methods, and study design choices will be available for you to choose from-allowing you priority alerts to cutting-edge research in your field!

\section{Disputes \& Debates: Rapid online correspondence}

The editors encourage comments on recent articles through Disputes \& Debates:

Access an article at Neurology.org/N and click on "COMMENT" beneath the article header. Responses will be posted within 3 business days.

Before submitting a comment to Disputes \& Debates, remember the following:

- Disputes \& Debates is restricted to comments about studies published in Neurology within the last eight weeks

- Read previously posted comments; redundant comments will not be posted

- Your submission must be 200 words or less and have a maximum of five references; reference one must be the article on which you are commenting

- You can include a maximum of five authors (including yourself) 


\section{Neurology}

\section{Mastoid osteoma with stenosis of transverse and sigmoid sinuses as a cause of pseudotumor cerebri}

Gustavo Lima Guarneri and Bernardo Corrêa de Almeida Teixeira

Neurology 2019;93;37-38

DOI 10.1212/WNL.0000000000007727

\section{This information is current as of July 1, 2019}

\section{Updated Information \&} Services

References

\section{Subspecialty Collections}

Permissions \& Licensing

Reprints including high resolution figures, can be found at: http://n.neurology.org/content/93/1/37.full

This article cites 2 articles, 1 of which you can access for free at: http://n.neurology.org/content/93/1/37.full\#ref-list-1

This article, along with others on similar topics, appears in the following collection(s):

Idiopathic intracranial hypertension

http://n.neurology.org/cgi/collection/idiopathic_intracranial_hypertensi on

\section{Optic nerve}

http://n.neurology.org/cgi/collection/optic_nerve

Information about reproducing this article in parts (figures,tables) or in its entirety can be found online at:

http://www.neurology.org/about/about_the_journal\#permissions

Information about ordering reprints can be found online:

http://n.neurology.org/subscribers/advertise

Neurology ${ }^{\circledR}$ is the official journal of the American Academy of Neurology. Published continuously since 1951, it is now a weekly with 48 issues per year. Copyright () 2019 American Academy of Neurology. All rights reserved. Print ISSN: 0028-3878. Online ISSN: 1526-632X.

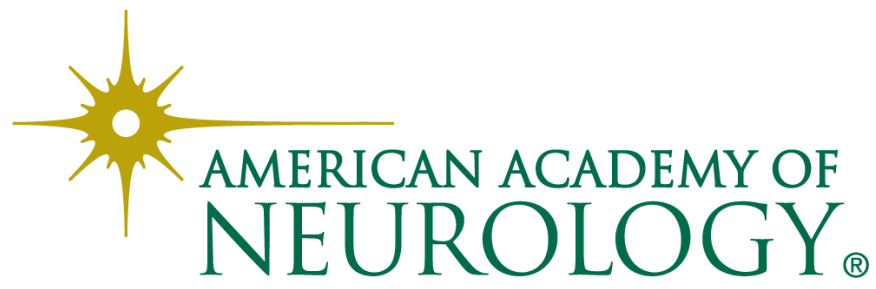

